http://dx.doi.org/10.11646/phytotaxa.163.1.6

\title{
First record of Vandellia diffusa (Linderniaceae) in Asia
}

\author{
MANGAVAYAL GOVINDAN PRASAD, KOLLANCHERI PUTHANVEETTIL VIMAL, KALATHUMMARATH \\ SHINOJ \& PURAYIDATHKANDY SUNOJKUMAR* \\ Department of Botany, University of Calicut, Kerala- 673 635, India \\ *Author for correspondence. E-mail: drsunoj@gmail.com
}

\begin{abstract}
Vandellia diffusa is reported for the first time from Asia. Its description, photographs, notes on distribution and habitat are provided for easy identification.
\end{abstract}

Key words: Linderniaceae, Vandellia, South India, Travancore coast, Kerala

\section{Introduction}

The genus Vandellia was established by Linnaeus (1767:384) and was treated under Scrophularieae (=Scrophulariaceae) by Jussieu (1789). Later on Bentham (1835) treated the genus under the tribe Gratioloeae. The generic circumscription of Vandellia along with Lindernia Allioni (1766: 178), Bonnaya Link \& Otto (1821: 25) and Ilysanthes Rafinesque (1820:13) has long been a serious matter of discussion among workers. These four genera were circumscribed mainly on the basis of the number of stamens and the nature of staminodes. However, Pennell (1935) considered that the characters so far used were too weak and artificial and combined all these taxa into a large genus Lindernia characterised by the remarkably uniform corolla, curiously recurving anterior filaments and by similar septicidal dehiscence of the capsule. This treatment was subsequently followed by majority of the authors (Philcox 1968, 2008; Sivarajan \& Mathew 1983; Yamazaki 1985, 1990; Fischer 1992, 1995, 2004; Lewis 2000). However, doubts arose due to the morphological heterogeneity (Fischer 1992) whether Lindernia was really monophyletic. Molecular phylogenetic studies (Olmstead \& Reeves 1995; Olmstead et al. 2001; Rahmanzadeh et al. 2005; Albach et al. 2005) revealed that traditional family Scrophulariaceae is polyphyletic and a new family Linderniaceae was emerged as a separate lineage including Lindernia with its relative genera. A recent study by Fischer et al. (2013) on phylogeny of the family Linderniaceae revealed that the genus Lindernia as accepted to date is shown to be polyphyletic and hence, the genera Bonnaya and Vandellia are resurrected together with Lindernia sensu stricto and a new genus Linderniella Eberhard Fischer, Bastian Schäferhoff \& Kai Müller (2013: 209).

The genus Vandellia L., characterized by pinnately veined leaves with serrate margins, having 4 fertile stamens, septicidal dehiscence of capsule and seeds with alveolate endosperm having bothrospermous surface, comprised about 52 species in the world. In India, it represents about 7 species (Fischer et al. 2013).

During field exploration at the Travancore coast of Kerala for the revisionary work of Linderniaceae of South India, the authors collected an interesting specimen of Vandellia from Kollam district of Kerala state. This on critical examination turned out to be Vandellia diffusa Linnaeus (1767: 422) (Fig.1) previously reported from Africa and tropical America.

This taxon was collected earlier from the nearby Alappuzha district (Sunil \& Sivadasan 2009) and was wrongly identified as L. sessiliflora (Bentham) Wettstein (1891: 79). Field observations revealed that this taxon flourishs well in the southern coastal areas in Kerala state. The occurrence of this species in this part of India forms the first report of its presence in Asia. 
Annual diffuse or creeping herb, spreads up to $30 \mathrm{~cm}$ long, rooting at the nodes. Stem 4-angled, pubescent, hairs more on angles. Leaves ovate or orbicular, sessile, margins crenate or shallowly serrate, base sub-cordate or rounded, apex acute or sub-acute, glabrous above, sparsely hairy on veins beneath, pinnately $3-5$ veined. Flowers solitary in leaf axils, sessile or sub-sessile, white with purplish tinge on the upper lip. Calyx tubular, keeled, $7.5 \times 2$ $\mathrm{mm}$, pale green, hispid, distinctly 5-lobed, lobes unequal, as long as or slightly longer than $3 \mathrm{~mm}$ long tube. Corolla creamy white with purplish tinge on the upper lip, tube $\pm 5 \mathrm{~mm}$ long, cylindrical, widens towards the apex, upper lip $3 \times 3 \mathrm{~mm}$, apex sub-acute, purplish, glabrous, lower lip distinctly 3 lobed, white with yellow marking on mid portion where lower stamens arise, lobes rounded, $3 \times 2 \mathrm{~mm}$. Stamens 4 , all fertile, posterior filaments short, ca. $1 \mathrm{~mm}$ long, glabrous, anthers coherent, anterior filaments long bended towards the upper lip, base blended, glandular hairy, $\pm 4 \mathrm{~mm}$ long, anthers coherent, 2-lobed, lobes ovate. Gynoecium $7-7.5 \mathrm{~mm}$ long, ovary $2.5 \times 1 \mathrm{~mm}$, ovate, glabrous, slightly bend at the base of the style, style slender, ca. $5 \mathrm{~mm}$ long, cylindrical, glabrous, stigma bifid. Capsule $12 \times 3 \mathrm{~mm}$, glabrous, ovate-linear, apex slightly bended, acuminate with persistant style, fruiting calyx $3 / 4$ length of fruit. Seeds many, minute, yellowish, alveolate, bothrospermous.

Specimens Examined:-INDIA, Kerala: Alappuzha district, Vallikavu-Chengannore, C.N. Sunil 1787 (CALI); Kollam district, Ochira, Vallikavu, 9 October 2013, M.G. Prasad 117889 (CALI).

Distribution and habitat:-The species has been reported previously from Africa (Senegal, Sierra Leone, Liberia, Côted'Ivoire, Burkina Faso, Ghana, Togo, Nigeria, Cameroon, Equatorial Guinea (Annobón, Bioko), São Tomé and Príncipe, Gabon, Central African Republic, Congo-Brazzaville, Congo-Kinshasa, Burundi, Uganda, Tanzania and Madagascar) and tropical America (introduced in Mexico, Belize, Costa Rica, Guatemala, Honduras, Panama, Cuba, Dominica, Dominican Republic, Grenada, Guadeloupe, Jamaica, Martinique, Puerto Rico, Saint Vincent and the Grenadines, Trinidad and Tobago, Bolivia, Brazil, Colombia, Ecuador, Guyana, Peru, Suriname and Venezuela) (Fischer et al. 2013). The newly discovered population grows in the sandy soils in south-west coast of India (Travancore coast).

\section{Acknowledgements}

The authors are grateful to the Forest department, Kerala state, for permission to undertake field studies in protected areas and to Dr. A. K. Pradeep, Assistant Professor, Department of Botany, University of Calicut, for his valuable comments on the manuscript. PS thanks the Department of Science \& Technology, Government of India for the financial support (Order No. SR/FD/LS-119/2010) and MGP thanks University Grants Commission for Rajiv Gandhi Fellowship.

\section{References}

Albach, D.C., Meudt, H.M. \& Oxelman, B. (2005) Piecing together the "new" Plantaginaceae. American Journal of Botany 92 : 297-315. http://dx.doi.org/10.3732/ajb.92.2.297

Allioni, C. (1766) Stirpium aliquot descriptiones. Mélanges de Philosophie et de Mathématique de la Société Royale de Turin 3(1): 176-185.

Bentham, G. (1835) Scrophularineae Indicae: A synopsis of the East Indian Scrophularineae contained in the collections presented by the East India Company to the Linnaean Society of London and in those of Mr. Royle and others; with some general observations on the affinities and sub-divisions of the order, James Ridgway \& Sons, London. http://dx.doi.org/10.5962/bhl.title.50876

Fischer, E. (1992) Systematik der afrikanischen Lindernieae (Scrophulariaceae). Tropische und Subtropische Pflanzenwelt 81: 1-365.

Fischer, E. (1995) Revision of the Lindernieae (Scrophulariaceae) in Madagascar. 1. The genera Lindernia Allioni and Crepidorhopalon E. Fischer. Bulletin du Muséum National d'Histoire Naturelle. Section B, Adansonia: Botanique Phytochemie ser. 4, 17: 227-257.

Fischer, E. (2004) Scrophulariaceae. In: Kadereit J. W. (ed.) The families and genera of vascular plants 7. Flowering plants. Dicotyledons. Lamiales (except Acanthaceae including Avicenniaceae). Berlin, Heidelberg, New York, pp. 333-432.

Fischer, E., Schäferhoff, B. \& Müller, K. (2013) The phylogeny of Linderniaceae - The new genus Linderniella, and new combinations within Bonnaya, Craterostigma, Lindernia, Micranthemum, Torenia and Vandellia. Willdenowia 43: 209238. 
http://dx.doi.org/10.3372/wi.43.43201

Jussieu de, A.L. (1789) Antonii Laurentii de Jussieu Genera plantarum: secundum ordines naturales disposita, juxta methodum in Horto regio parisiensi exaratam, Parisiis, pp. 117-123.

http://dx.doi.org/10.5962/bhl.title.284

Lewis, D.Q. (2000) A revision of the New World species of Lindernia (Scrophulariaceae). CASTENEA 65(2): 93-122.

Link, J.H.F \& Otto, C.F (1820) Icones Plantarum Selectarum Horti Regii Botanici Berolinensis, p. 25, t.11. http://dx.doi.org/10.5962/bhl.title.51952

Linnaeus, C. (1767) Mantissa Plantarum. Generum Editionis vi et Specierum Editionis ii. Laurentius Salvius, Stockholm, 89 pp.

Linnaeus, C. (1767) Systema naturae per regna tria naturae: secundum classes, ordines, genera, species, cum characteribus, differentiis, synonymis, locis, ed. 12, Vol. 2, Vindobonae: Typis Ioannis Thomae. http://dx.doi.org/10.5962/bhl.title.37256

Olmstead, R.G. \& Reeves, P.A. (1995) Evidence for the polyphyly of the Scrophulariaceae based on chloroplast $r b c L$ and $n d h F$ sequences. Annals of the Missouri Botanical Garden 82: 176-193. http://dx.doi.org/10.2307/2399876

Olmstead, R.G., De Pamphilis, C.W., Wolfe, A.D., Young, N.D., Ellisons, W.J. \& Reeves, P.A. (2001) Disintegration of the Scrophulariaceae. American Journal of Botany 88: 348-361. http://dx.doi.org/10.2307/2657024

Pennell, F.W. (1935) The Scrophulariaceae of eastern temperate North America. Academy of Natural Sciences of Philadelphia Monographs 1: 1-650.

Philcox, D. (2008) Lindernia. In: GhazanfarS. A., Hepper F. N. \& Philcox D. (eds.) Scrophulariaceae, Flora of Tropical East Africa. Royal Botanic Gardens, Kew, pp. 67-91.

Philcox, D. (1968) Revision of the Malesian species of Lindernia All. (Scrophulariaceae). Kew Bulletin 22: 1-72. http://dx.doi.org/10.2307/4107820

Rafinesque, C.S. (1820) Annals of Nature, Lexington. Vol.1, 13 pp.

Rahmanzadeh, R., Müller, K., Fischer, E., Bartels, D. \& Borsch, T. (2005) Linderniaceae and Gratiolaceae are further lineages distinct from Scrophulariaceae (Lamiales). Plant Biology (Stuttgart) 7: 1-11. http://dx.doi.org/10.1055/s-2004-830444

Sivarajan, V.V. \& Mathew, P. (1983) The genus Lindernia All. (Scrophulariaceae) in India. Journal of the Bombay Natural History Society 80(1): 131-140.

Sunil, C.N. \& Sivadasan, M. (2009) Flora of Alappuzha District, Kerala, India. Bishen Sing Mahendra Pal Sing, Dehra Dun, $505 \mathrm{pp}$.

Wettstein von, R. (1891) Scrophulariaceae. In: Engler A. \& Prantl K. (eds.) Die natürlichen Pflanzenfamilien, ed. 1895. T. 4, Abt.3b. p.79.

Yamazaki, T. (1985) Scrophulariacées. In: Leroy J.F. (ed.) Flore du Cambodge, du Laos et du Viêt-Nam 21. Muséum National d'Histoire Naturelle, Paris, pp. 1-217.

Yamazaki, T. (1990) Scrophulariaceae. In: Smitinand, T. \& Larsen, K. (ed.) Flora of Thailand 5(2). The Forest Herbarium, Royal Forest Department, Bangkok, pp. 139-238. 